\title{
HUBUNGAN PENGETAHUAN DENGAN TINDAKAN TENTANG PEMELIHARAAN KESEHATAN GIGI DAN MULUT PADA ANAK USIA 11 - 12 TAHUN DI SDN 020583 KOTA BINJAI TAHUN 2016
}

\author{
Relationship of Knowledge With Action About Dental And Mouth Health \\ Maintenance in Children Ages 11 - 12 Years in State SDN 020583 \\ City Of Binjai in 2016
}

\author{
Irma Handayani ${ }^{1}$ \\ ${ }^{1}$ Dosen Akademi Keperawatan Sehat Binjai \\ E-mail: handay1502@gmail.com
}

\begin{abstract}
Abstrak
Pendidikan kesehatan gigi dan mulut merupakan salah satu upaya untuk meningkatkan gigi dan mulut usia sekolah dasar merupakan usia yang ideal untuk melatih kemampuan motorik seorang anak tujuan dalam penelitian ini adalah untuk mengetahui hubungan pengetahuan dan tindakan tentang pemeliharaan kesehatan gigi dan mulut pada anak usia 11-12 tahun SDN 020583 kota binjai taun 2016. Dalam hal ini peneliti mengambil jenis penelitian korelasi yang bertujuan untuk menggungkapkan hubungan pengetahuan dengan tindakan tentang pemeliharaan kesehatan gigi dan mulut pada anak usia 11-12 tahun. Sampel dalam penelitian ini adalah siswa siswi usia 11-12 tahun di SDN 020583 kota binjai sebanyak 32 orang instrumen yang digunakan dalam penelitian ini adalah kuesioner yang berisikan 20 pertanyaan. Data kemudian dianalisa kedalam bentuk tabel karakteristik tingkat pengetahuan dan perilaku responden kemudian dipersentasikan. Hasil penelitian $r$ hitung $(0,581)>r$ tabel maka hipotesis alternatif diterima tidak ada hubungan yang signifikan, maka ada hubungan pengetahuan dengan tindakan tentang pemeliharaan gigi dan mulut pada anak usia11-12 tahun di SDN 020583 kota binjai 2016. Berdasarkan perhitungan $\mathrm{t}$ hitung maka diperoleh $\mathrm{t}$ hitung : dalam hasil perhitungan ini menunjukan bahwa nilai $\mathrm{t}$ hitung $(18,182)>\mathrm{t}$ tabel $(2,042)$. Jika $\mathrm{t}$ hitung $>\mathrm{t}$ tabel hipotesis altenatif diterima artinya ada hubungan yang signifikan, maka ada hubungan pengetahuan dengan tindakan tentang pemeliharaan kesehatan gigi dan mulut pada anak usia11-12 tahun di SDN 020583 kota binja Tahun 2016
\end{abstract}

Kata kunci : Pengetahuan, tindakan anak gigi dan mulut

\begin{abstract}
Dental and oral health education is one of the efforts to improve dental and oral primary school age is the ideal age to train motor skills of a child. The purpose of this study was to determine the relationship between knowledge and actions about maintaining oral health in children aged 11-12 year SDN 020583 binjai city year 2016. In this case the researcher took a type of correlation study which aims to reveal the relationship of knowledge with actions on maintaining dental and oral health in children aged 11-12 years. The sample in this study were students aged 11-12 years in SDN 020583 in the city of Binjai as many as 32 people the instruments used in this study were questionnaires containing 20 questions. Data is then analyzed in the form of table characteristics of the level of knowledge and behavior of the respondents then presented. The results of the study $r$ count $(0.581)>r$ table so that the alternative hypothesis is accepted there is no significant relationship, then there is a relationship of knowledge with actions about the maintenance of teeth and mouth in children aged 11-12 years in SDN 020583 in Bandung 2016. $t$ count: in the results of this calculation show that the value of $t$ count $(18,182)>t$ table $(2,042)$. If $t$ count $>t$ tables of alternative hypotheses are accepted, it means that there is a significant relationship, then there is a relationship of knowledge with actions on maintaining dental and oral health in children aged 11-12 years in SDN 020583 in the city of 2016
\end{abstract}

Keywords: Knowledge, actions of the child's teeth and mouth 


\section{PENDAHULUAN}

Pendidikan kesehatan gigi dan mulut merupakan salah satu upaya untuk meningkatkan kesehatan gigi dan mulut pada anak, penyuluhan harus dibuat semenarik mungkin, atraktif tanpa mengurangi isinya. Pendidikan dilakukan melalui demonstrasi secara langsung, program audio visual, atau melalui sikat gigi masal yang terkontrol.

Anak-anak memang masih dalam taraf memerlukan bimbingan yang ketat, memerlukan kesadaran yang luar biasa, memerlukan kebijaksanaan yang sempurna, memerlukan cara yang baik. Anak-anak belum dapat bersikat gigi secara betul dan mungkin saja malah tidak mau. Maka dariitu harus dicari cara agar anak-anak senang bersikat gigi. Caranya ialah, ketika masih usia gigi tumbuh, yakni setelah usia enam bulan, mulai diperlihatkan cara-cara bersikat gigi (Machfoedz, 2008). Menurut Dekan Fakultas Kedokteran Gigi Universitas Indonesia, Sri Angky Soetanto, penyakit karies atau gigi berlubang merupakan penyakit infeksi yang umum di dunia dan ditemukan pada $95 \%$ jumlah penduduk dunia. Angka kerusakan gigi di Indonesia berdasarkan survey kesehatan yang dilakukan Departemen Kesehatan RI pada tahun 2013terjadi peningkatan prevalensi terjadinya karies aktif pada penduduk indonesia dibandingkan tahun 2007 lalu, yaitu dari 43,4\% (2007) menjadi 53,2 \% (2013). Suatu peningkatan yang cukup tinggi jika dilihat dari besaran kesehatan masyarakat indonesia.

Menurut data WHO bila ditinjau dari kelompok umur penderita karies aktif terjadi peningkatan pula prevalensinya dari tahun 2007 ke tahun 2013, dengan peningkatan terbesar pada usia 12 tahun $(13,7 \%)$ dan 65 tahun lebih $(14,3 \%)$.

Salah satu faktor yang mempengaruhui kesehatan gigi dan mulut adalah tingkat pengetahuan, dan tindakan. Pengetahuan kesehatan gigi dan mulut di peroleh melalui proses kognitif yang kompleks. Penelitian ini menunjukkan bahwa terdapat hubungan antara peningkatan pengetahuan mengenai kesehatan gigi dan mulut (Arikunto, 2012).
Penjelasan tentang hubungan pengetahuan dengan pemeliharan kesehatan gigi dan mulut. Berdasarkan penelitian yang dilakukan oleh Ardiansyah (2013) dengan judul "Hubungan Pengetahuan Dan Perilaku Dengan Pemeliharaan Kesehatan Gigi Dan Mulut Pada Anak Usia 11-12 Tahun Di SD Taman Siswa Binjai 2016". Di dapat hasil yang menunjukkan ada hubungan pengetahuan dan tindakan dengan pemeliharaan kesehatan gigi dan mulut pada anak usia 11-12 tahun di SD Taman Siswa Kota Binjai.Hal ini sejalan dengan nurjannah (2014) Pelajar Smp Ummul Mukminin di Kota Medan. Mengatakan bahwa terdapat hubungan yang bermakna antara pengetahuan dan tindakan dengan kesehatan gigi dan mulut pada pelajar Smp ummul mukminin Kota Medan tahun 2016.

Dari uraian diatas peneliti tertarik untuk melakukan penelitian yang berjudul "Hubungan Pengetahuan dengantindakan tentangPemeliharaan Kesehatan Gigi dan Mulut Pada Anak Usia 11-12 Tahun di SDN 020583 Kota Binjai”.

\section{METODE}

Dalam hal ini peneliti mengambil jenis penelitian korelasi yang bertujuan untuk mengungkapkan hubungan pengetahuan dengan perilaku pemeliharaan kesehatan gigi dan mulut pada anak usia 11-12 tahun, yang dalam hal ini jenis penelitian melibatkan 2 variabel.

Adapun lokasi yang diambil dalam penelitian ini yaitu SDN 020583 Kota Binjai. Pemilihan lokasi penelitian ini berdasarkan survey awal peneliti yang masih banyak nya anak usia 11-12 tahun yang belum mengetahui cara perawatan kesehatan gigi dan mulut dengan baik dan benar.

Penelitian ini akan dilakukan pada bulan Februari-Mei di tahun 2016. Populasi dalam penelitian ini adalah siswa - siswa kelas 6 SD usia 11 - 12 tahun sebanyak 32 orang di Kota Binjai. Dalam penelitian ini penulis menggunakan teknik pengambilan sampel dengan menggunakan total sampling. yaitu seluruh siswa kelas 6 SD usia $11-12$ tahun sebanyak 32 orang di SDN 020583 Kota Binjai sebanyak 32 orang. 
HASIL PENELITIAN

Tabel 4.1 Distribusi Responden penelitian Berdasarkan Kelompok Umur Di SDN 020583 Kota Binjai Tahun 2016

\begin{tabular}{cccc}
\hline No & Umur & Frekuensi & Persentasi \\
\hline 1 & 11 & 14 & $44 \%$ \\
2 & 12 & 18 & $56 \%$ \\
\hline & Jumlah & $\mathbf{3 2}$ & $\mathbf{1 0 0} \%$ \\
\hline
\end{tabular}

Berdasarkan tabel diatas dapat diketahui bahwa dari 32 responden yang berusia 11 tahun sebanyak 14 orang (44\%), dan yang berusia 12 tahun sebanyak 18 orang (56\%).

Tabel 4.2 Distribusi Responden Bedasarkan Jenis Kelamin Di SDN 020583 Kota Binjai 2016

\begin{tabular}{cccc}
\hline No & Jenis Kelamin & Jumlah & Persentase \\
\hline 1 & Laki - laki & 18 & $56 \%$ \\
2 & Perempuan & 14 & $44 \%$ \\
\hline & Jumlah & 32 & $100 \%$ \\
\hline
\end{tabular}

Dari tabel diatas diketahui bahwa dari 32 reponden yang berjenis kelamin laki - laki da 18 orang $(56 \%)$, dan berjenis kelamin perempuan ada 14 orang $(44 \%)$.

\section{Distribusi Hasil Kuisioner}

Dari 32 responden peneliti ingin mengetahui lebih jauh hubungan pengetahuan dan perilaku tentang pemeliharaan kesehatan gigi dan mulut pada anak usia $11-12$ tahun di SDN 020583 Kota Binjai dengan kuisioner sebanyak 32 reponden.

Tabel 4.3 Distribusi Jawaban Responden Berdasarkan Pengetahuan Anak Usia 11-12 Tahun Dengan Pemeliharaan Kesehatan Gigi Dan Mulut

\begin{tabular}{cccc}
\hline No & Pengetahuan & Frekuensi & Persentase \\
\hline 1 & Baik & 10 & $31 \%$ \\
2 & Cukup & 8 & $25 \%$ \\
3 & Kurang & 14 & $44 \%$ \\
\hline & Jumlah & 32 & $100 \%$ \\
\hline
\end{tabular}

Dari data di atas dapat dilihat bahwa distribusi responden berdasarkan pengetahuan anak usia 11-12 tahun di SDN 020583 di kota binjai 2016, rata - rata memiliki pengetahuan baik ada 10 orang $(31 \%)$, memiliki pengetahuan cukup ada 8 orang $(25 \%)$ dan memiliki pengetahuan kurang ada 14 orang $(44 \%)$.

Tabel 4.4 Distribusi Jawaban Responden Berdasarkan Tindakan Anak Usia 11-12 Tahun Dengan Pemeliharaan Kesehatan Gigi Dan Mulut

\begin{tabular}{cccc}
\hline No & Perilaku & Frekuensi & Persentasi \\
\hline 1 & Baik & 15 & $47 \%$ \\
2 & Tidak Baik & 17 & $53 \%$ \\
\hline & Jumlah & 32 & $100 \%$ \\
\hline
\end{tabular}


Dari tabel diatas dapat dilihat bahwa distribusi responden berdasarkan perilaku anak usia 11 -12 tahun di SDN 020583 Kota Binjai tahun 2016, rata - rata memiliki perilaku baik ada 15 orang (47\%), dan memiliki perilaku tidak baik ada 17 orang (53\%)

Tabel 4.5 Distribusi Variabel X Dan Y Hubungan Pengetahuan Dengan Tindakan Tentang Pemeliharaan Kesehatan Gigi Dan Mulut Pada Anak Usia 11-12 Tahun Di SDN 020583 Di Kota Binjai

\begin{tabular}{ccccccc}
\hline No & $\begin{array}{c}\text { Nama } \\
\text { responden }\end{array}$ & $\mathbf{X}$ & $\mathbf{Y}$ & $\mathbf{X}^{\mathbf{2}}$ & $\mathbf{Y}^{\mathbf{2}}$ & $\mathbf{X Y}$ \\
\hline 1 & An.W & 8 & 7 & 64 & 49 & 56 \\
2 & An.A & 6 & 6 & 36 & 36 & 36 \\
3 & An.R & 6 & 6 & 36 & 36 & 36 \\
4 & An.U & 8 & 4 & 64 & 16 & 32 \\
5 & An.W & 3 & 3 & 9 & 9 & 9 \\
6 & An.U & 2 & 4 & 4 & 16 & 8 \\
7 & An.M & 5 & 2 & 25 & 4 & 10 \\
8 & An.A & 9 & 7 & 81 & 49 & 63 \\
9 & An.R & 8 & 7 & 64 & 49 & 56 \\
10 & An.U & 7 & 7 & 49 & 49 & 49 \\
11 & An.L & 6 & 4 & 36 & 16 & 32 \\
12 & An.A & 8 & 4 & 64 & 16 & 32 \\
13 & An.F & 3 & 2 & 9 & 4 & 6 \\
14 & An.A & 4 & 4 & 16 & 16 & 16 \\
15 & An.U & 5 & 4 & 25 & 16 & 20 \\
16 & An.R & 9 & 7 & 81 & 49 & 63 \\
17 & An.A & 8 & 6 & 64 & 36 & 48 \\
18 & An.H & 6 & 6 & 36 & 36 & 36 \\
19 & An.M & 8 & 6 & 64 & 36 & 48 \\
20 & An.A & 2 & 3 & 4 & 9 & 6 \\
21 & An.T & 7 & 6 & 49 & 36 & 42 \\
22 & An.M & 4 & 2 & 16 & 4 & 8 \\
23 & An.A & 5 & 3 & 25 & 9 & 15 \\
24 & An.R & 8 & 7 & 64 & 49 & 56 \\
25 & An.U & 2 & 3 & 4 & 9 & 6 \\
26 & An.N & 6 & 6 & 36 & 36 & 36 \\
27 & An.D & 3 & 4 & 9 & 16 & 12 \\
28 & An.U & 2 & 2 & 4 & 4 & 4 \\
29 & An.R & 8 & 7 & 64 & 49 & 56 \\
30 & An.I & 4 & 2 & 16 & 4 & 8 \\
31 & An.O & 3 & 4 & 9 & 16 & 12 \\
32 & An.K & 7 & 6 & 49 & 36 & 42 \\
\hline & JUMLAH & $\sum \mathrm{X}=180$ & $\sum \mathrm{Y}=151$ & $\sum \mathrm{X}^{2}=1.176$ & $\sum \mathrm{Y}^{2}=815$ & $\sum \mathrm{XY}$ \\
& & & & & & $=959$ \\
\hline & & & & & & \\
\hline
\end{tabular}

Dengan demikian nilai $\mathrm{t}$ table di disribusi dengan $\alpha=0,05$. Di dapatkan $\mathrm{t}$ table $=$ 2,042 Bedasarkan perhitungan tersebut, maka diperoleh nilai $r$ hitung $=0,846$. Dalam table $r$ dinyatakan bahwa untuk $\mathrm{n}=32$, maka dengan taraf signifikan $5 \%$ nilai $\mathrm{r}$ table adalah 0,349 . Dengan demikian hasil perhitungan ini menunjukkan bahwa nilai $r$ hitung $(0,846)>\mathrm{r}$ table $(0,349)$. Dengan demikan hipotesis alternative diterima.

Table 4.6 Korelasi T Hitung Dan T Table

\begin{tabular}{cccc}
\hline No Item & T Hitung & T Tabel & Keputusan \\
\hline 1 & 6,343 & 2,042 & Valid \\
\hline
\end{tabular}


PEMBAHASAN

\section{Karakteristik Responden}

Dalam hal ini penelitian ini yang di jadikan sampel adalah anak usia 11- 12 tahun di SDN 020583 Kota Binjai tahun 2016. Hasil penelitian ini menunjukkan bahwa hubungan pengetahuan dengan tindakan pada anak usia $11-12$ tahun Di SDN 020583 Kota Binjai.

Bedasarkan kelompok umur dari 32 responden $(100 \%)$ mayoritas berusia 12 tahun berjumlah 18 orang (56\%), dan berusia 11 tahun berjumlah 14 orang (44\%), dalam hal ini tidak terdapat kesenjangan dalam penelitian dan teoritis, karena menurut abdul ghofur usia anak sekolah sangat diperlukan pengetahuan dengan tindakan yang baik dalam pemeliharaan kesehatan gigi dan mulut apabila pengetahuan dengan tindakan kurang baik maka kesehatan gigi dan mulutnya akan berakibat buruk atau gigi dan mulutnya akan tidak sehat.

Karakteristik hubungan antara pengetahuan dengan tindakan anak usia 1112 tahun tentang pemeliharaan kesehatan gigi dan mulut di SDN 020583 kota binjai tahun 2016 bedasarkan jenis kelamin dari 32 responden (100\%), mayoritas berjenis kelamin laki - laki berjumlah 18 orang (56\%) dan berjenis kelamin perempuan berjumlah 14 orang (44\%),

Dalam hal ini tidak terdapat kesejangan antara teoritis dan penelitian, karena menurut google cendikia pemeliharaan gigi dan mulut pada anak laki - laki sering terjadi kerusakan gigi dan mulut karena anak laki - laki lebih rentan mengalami kerusakan gigi dan mulut akibat sering sembarang mengkomsumsi makanan, karena kurangnya pengetahuan dan perilaku seseorang terhadap pemeliharaan kesehatan gigi dan mulut.

\section{Hubungan pengetahuan dengan tindakan tentang pemeliharaan kesehatan gigi dan mulut pada anak usia 11 - 12 tahun tentang pemeliharaan kesehatan gigi dan mulut.}

Dari hasil penelitian dapat diketahui bahwa dalam 32 responden pengetahuan
Anak usia $11 \quad-12$ tahun dengan pemeliharaan kesehatan gigi dan mulut di SDN 020583 kota binjai tahun 2016, yang mayoritas memiliki pengetahuan kurang.

Setelah dilakukan penelitian terhadap hubungan pengetahuan dan perilaku tentang pemeliharaan kesehatan gigi dan mulut pada anak usia 11-12 tahun di SDN 020583 kota binjai, maka dapat disimpulkan sebagai berikut :

1. Dari hasil penelitian dapat diketahui bahwa mayoritas memiliki pengetahuan kurang berjumlah 14 orang (44\%), memiliki pengetahuan baik berjumlah 10 orang $(31 \%)$ dan memiliki pengetahuan cukup berjumlah 8 orang $(25 \%)$.

2. Dari hasil penelitian dapat diketahui bahwa yang mayoritas memiliki tindakan tidak baik berjumlah 17 orang ( $53 \%$ ), dan memiliki tindakan baik berjumlah 15 orang ( $47 \%$ ).

3. Maka dengan taraf signifikan $5 \%$ hasil perhitungan ini menunjukan bahwa nilai $\mathrm{r}$ hitung $0,846>\mathrm{r}$ table 0,349 . Dengan demikian hipotesis alternatif (Ha) diterima, artinya ada hubungan antara pengetahuan dengan tindakan tentang pemeliharaan kesehatan gigi dan mulut pada anak usia 11-12 tahun di SDN 020583 Kota Binjai.

\section{SARAN}

Saran yang dapat peneliti berikan berdasarkan hasil penelitian yang ditemukan sebagai berikut : berjumlah 14 orang (44\%), memiliki pengetahuan baik berjumlah 10 orang $(31 \%)$, dan memiliki pengetahuan cukup berjumlah 8 orang $(22 \%)$.

Anak-anak mayoritas memiliki pengetahuan kurang dikarenakan kurangnya informasi dan tidak adanya bimbingan dari orang tua maupun dari guru sekolah tentang pemeliharaan kesehatan gigi dan mulut dengan baik dan benar seperti menyikat gigi sebelum tidur dan sesudah sarapan pagi. Anak-anak memiliki pengetahuan baik karena sejak dini anak-anak tersebut telah mendapat bimbingan dari orang tua tentang pemeliharaan kesehatan gigi dan mulut seperti menyikat gigi sebelum tidur dan menyikat gigi sesudah sarapan pagi. 
Karena pengetahuan sangat penting dalam pemeliharaan kesehatan gigi dan mulut. Karena menurut wikipedia pengetahuan anak sangat mempengaruhi pemeliharaan kesehatan gigi dan mulut apabila kurangnya pengetahuan anak maka akan berkurang pemeliharaan kesehatan gigi dan mulut pada anak tersebut.

Perilaku anak dari 32 responden (100 \%) usia 11-12 tahun dengan pemeliharaan kesehatan gigi dan mulut di SDN 020583 kota binjai tahun 2016 mayoritas yang memiliki tindakan tidak baik ada 17 orang (53\%). Anak-anak memiliki tindakan tidak baik terhadap pemeliharaan kesehatan gigi dan mulut karena kurangnya bimbingan dari orang tua atau guru sekolah tentang waktu yang baik untuk menyikat gigi seperti sebelum tidur dan sesudah sarapan pagi. Karena menurut wikepedia nootoadmodjo perilaku sangat diperlukan dalam pemeliharaan kesehatan gigi dan mulut karena apabila perilaku anak kurang baik dalam pemeliharaan kesehatan gigi dan mulut akan menyebabkan komplikasi pada gigi dan mulut.

Dari data tabel 4.3 dapat dilihat bahwa distribusi responden berdasarkan pengetahuan anak usia 11-12 tahun di SDN 020583 di kota binjai 2016, rata - rata memiliki pengetahuan baik ada 10 orang (31\%), memiliki pengetahuan cukup ada 8 orang $(25 \%)$ dan memiliki pengetahuan kurang ada 14 orang (44\%).

Dari tabel 4.4 dapat dilihat bahwa distribusi responden berdasarkan perilaku anak usia $11-12$ tahun di SDN 020583 Kota Binjai tahun 2016, rata-rata memiliki perilaku baik ada 15 orang (47\%), dan memiliki perilaku tidak baik ada 17 orang $(53 \%)$.

Hasil penelitian $r$ hitung $>r$ tabel maka hipotesis alternatif diterima tidak ada hubungan yang signifikan, maka ada hubungan pengetahuan dengan tindakan tentang pemeliharaan gigi dan mulut pada anak usia11-12 tahun di SDN 020583 kota binjai 2016. Berdasarkan perhitungan $\mathrm{t}$ hitung maka diperoleh $t$ hitung : dalam hasil perhitungan ini menunjukan bahwa nilai $t$ hitung ()>t tabel (). Jika $\mathrm{t}$ hitung $>\mathrm{t}$ tabel hipotesis altenatif diterima artinya ada hubungan yang signifikan, maka ada hubungan pengetahuan dengan tindakan tentang pemeliharaan kesehatan gigi dan mulut pada anak usia11-12 tahun di SDN 020583 kota binja Tahun 2016.

\section{KESIMPULAN}

1. Bagi Institusi Pendidikan

Diharapkan supaya menambah bukubuku tentang pemeliharaan kesehatan gigi dan mulut supaya lebih mempermudah mahasiswa dalam melaksanakan proses belajar.

\section{Bagi Peneliti}

Semoga karya tulis ilmiah yang dibuat ini dapat bermanfaat bagi peneliti dan mahasiswa lainnya sebagai bahan masukkan.

3. Bagi Responden

Diharapkan kepada siswi dan siswa umumnya untuk meningkatkan pengetahuan dengan menambah wawasan dari berbagai informasi mengenai kesehatan pemeliharaan gigi dan mulut.

Diharapkan kepada siswi dan siswa agar selalu menjaga kebersihan terutama sebelum tidur dan sesudah sarapan pagi dan melakukan pola hidup sehat.

4. Bagi Peneliti Selanjutnya

Diharapkan pola peneliti selanjutnya untuk melakukan peneliti yang lebih luas lagi tentang masalah pemeliharaan kesehatan gigi dan mulut

\section{DAFTAR PUSTAKA}

Anik, 2017. Perilaku Hidup Bersih Dan Sehat. Cetakan Kedua. Jakarta: Tim 2017.

Arikunto, 2006. Metodologi Penelitian Suatu Pendekatan Proposal. Jakarta : PT. Rineka Cipta.

Ghofur, A. 2012. Buku Pintar kesehatan Gigi Dan Mulut. Yogyakarta: Mitra Buku.

Hidayat, A,A, 2008. Riset Keperawatan Dan Teknik Penulisan Ilmiah. Edisi Kedua. Jakarta:Selemba Medika.

Hidayat, A,A, 2007. Metode Penilitian Keperawatan Dan Teknik Analisa Data. Jakarta:Selemba Medika.

Machfoedz, I. 2008. Menjaga Kesehatan Gigi Dan Mulut Pada Anak - Anak 
Dan Ibu Hamil. Yogyakarta: Fitramaya.

Notoatmodjo, 2010. Metodologi Penelititan Kesehatan. Jakarta: Rineka Cipta.

Notoatmodjo, Soekidjo, 2003. Pendidikan Dan Perilaku Kesehatan. Jakarta: Rineka Cipta.

Hernita, 2016. Seputar Kesehatan Gigi Dan Mulut. Jogjakarta: Rapha Publising.

Wawan, D. 2011. Teori Dan Pengukuran Pengetahuan, Sikap, Dan Perilaku Manusia. Cetakan II. Jakarta: Nuha Medika. 